\title{
The Role of PGE2 and its Corresponding Receptors (Ep1-4) in Oesophageal Carcinogenesis: Novel Therapeutics for Chemoprevention and/or Intervention
}

Michelle C. Lowry*, John V. Reynolds and Mary-Clare Cathcart

Department of Surgery, Institute of Molecular Medicine, Trinity Centre for Health Sciences, St. James's Hospital, Dublin, Ireland

*Corresponding author: Mary-Clare Cathcart, Department of Surgery, Institute of Molecular Medicine, Trinity Centre for Health Sciences, St. James's Hospital, Dublin 8, Ireland, Tel: +353 1896 3620; E-mail: cathcarm@tcd.ie

Received date: Jul 05, 2014, Accepted date: Jul 20, 2014, Published date: Jul 30, 2014

Copyright: @ 2014 Lowry MC, et al. This is an open-access article distributed under the terms of the Creative Commons Attribution License, which permits unrestricted use, distribution, and reproduction in any medium, provided the original author and source are credited.

\begin{abstract}
The incidence of oesophageal adenocarcinoma (OAC) is increasing. At present, OAC is the 7 th leading cause of cancer deaths worldwide. The use of aspirin and other non-steroidal anti-inflammatory drugs (NSAIDs) reduce the progression from Barrett's oesophagus (BO) to OAC. These cyclooxygenase (COX) targeted agents have demonstrated considerable promise, although long-term use has been associated with both gastrointestinal (GI) damage and increased cardiovascular risk. COX-2 overexpression is seen in BO and OAC patients and is a promising target for chemopreventive and/or therapeutic approaches. However, the unfavourable safety profile associated with long-term COX-2 targeting emphasizes the need to both understand and target specific downstream effector mechanisms. The role of pro-inflammatory prostaglandin E2 (PGE2) and its corresponding EP receptors have gained considerable attention in recent years, where they have been associated with tumourogenesis in a number of inflammatory-driven cancers, including OAC. This review will discuss the role of COX-derived PGE2 signalling in OAC development and progression, with specific emphasis on EP receptor expression and function. We will compare and contrast the potential of traditional NSAIDs, selective COX-2 inhibitors and EP antagonists as chemopreventive and/or therapeutic agents. Finally, we will discuss the promise of novel small molecule selective EP antagonists, which have recently been developed and are currently under clinical investigation.
\end{abstract}

Keywords: Adenocarcinoma; Cyclooxygenase; Tumourigenesis; Chemopreventive

\section{Introduction}

Oesophageal adenocarcinoma (OAC) is the 7th most common cause of cancer deaths and the eighth most common cancer worldwide [1]. The World Health Organization (W.H.O.) estimates that 410000 cases of OAC are presented annually, with an incidence that is increasing more than any other solid tumour [2]. Patients diagnosed with OAC have a very poor five year survival rate of $13 \%$, and $34-45 \%$ for those who can undergo treatment with curative intent [3]. First line therapy increasingly involves multimodality approaches, with chemotherapy, radiation therapy and esophagectomy, while there is no effective therapy for relapsed or metastatic disease. In this context, there is an urgent need for new strategies for prevention and early diagnosis as well as improved treatments. Cyclooxygenase-2 (COX-2) over-expression is seen in many cancers, including colorectal cancer, lung cancer, and $\mathrm{OAC}$, where it has frequently been shown to be a marker of poor prognosis [4-6]. COX-2 is a key factor in oesophageal carcinogenesis, with expression significantly increasing across the Barrett's to adenocarcinoma sequence [7,8]. NSAIDs act by inhibiting both COX-1 and COX-2. While reducing the risk of oesophageal cancer, these agents have also been associated with adverse gastrointestinal effects [9-11]. Selective COX-2 inhibition is therefore an important target in cancer prevention and/or treatment, with a scientific rationale. However, this approach is associated with adverse cardiovascular risk [12]. Therefore, selective targeting of downstream effectors of COX-2 may prove beneficial in cancer prevention. Targets currently being investigated include prostaglandin E2 (PGE2), prostaglandin synthases and EP receptors. The identification and development of alternative approaches to COX-2 inhibitors has the potential of avoiding the adverse effects associated with global COX-2/ prostanoid inhibition, while maintaining promising anti-tumour reactivity.

\section{Risk Factors and Epidemiology}

Many risk factors for the development of OAC have been identified in recent years, although new chemopreventive approaches have yet to be uncovered. Although OAC is predominantly recorded in males, the incidence in white females is also increasing $[13,14]$. In the USA, studies have found that the risk of OAC is greater in males aged 65 or older [14]. A case study of Kenyan OAC patients revealed striking epidemiological data, where patients in Western Kenya presented with $\mathrm{OAC}$ at 30 years old [15]. This study reveals the changing patterns in cancer incidence worldwide and suggests that further epidemiological studies are required to identify the predominant risk factors. . The first genome-wide study for the susceptibility of BO was conducted in 2012. A variant was observed within the major histocompatibility complex (MHC) locus on chromosome 6p21 (rs9257809), which may predispose individuals to the development of $\mathrm{BO}$ [16]. A second variant was found on chromosome 16q24 (rs9936833). The coding gene associated with this SNP was FOXF1 (forkhead family transcription factor). FOXF1 plays a role in the development of the oesophagus [16,17]. Obesity has become an epidemic in the Western world in recent years, while the incidence of OAC has also increased annually. According to W.H.O., the rate of obesity has doubled in the last two decades and $50 \%$ of Europeans are now overweight or obese [18]. While the exact cause of the increased incidence of OAC is still unknown, obesity has been shown to be increasingly involved, and is now considered a risk factor for OAC. The Barrett's genome-wide 
Citation: Lowry MC, Reynolds JV, Cathcart MC (2014) The Role of PGE2 and its Corresponding Receptors (Ep1-4) in Oesophageal Carcinogenesis: Novel Therapeutics for Chemoprevention and/or Intervention. J Carcinog Mutagen 5: 181. doi: $10.4172 / 2157-2518.1000181$

Page 2 of 10

study suggests an association between body weight measure (BMI (body mass index) and WHR (waist-hip ratio)) SNPs and BO development [16]. However, the exact mechanism by which obesity is associated with OAC has not fully been elucidated, but may be through reflux as well as promoting systemic and oesophageal inflammation.

Inflammatory diseases are risk factors for cancer development and progression. Hanahan and Weinburg considered tumour-promoting inflammation as the 7th hallmark of cancer [19]. Inflammatory conditions such as inflammatory bowel disease, Barrett's oesophagus (BO) and psoriasis have been linked to increased cancer risk [20-23]. The greatest risk factors for the development of OAC are gastrooesophageal reflux disease (GORD) and BO. Previous findings have linked obesity to the increased incidence of GORD and thus both conditions together may function synergistically in the progression to OAC [24]. BO is described as the pre-malignant lesion that predisposes to OAC. The annual incidence of OAC from $\mathrm{BO}$ is $0.4 \%$ [25]. Smoking has recently been identified as a risk factor for the development of $\mathrm{BO}$ [26]. In contrast the association between tobacco intake and OAC risk has not been fully elucidated with contradicting population studies [27].

\section{Barrett's Oesophagus and Oesophageal Adenocarcinoma Development}

Barrett's oesophagus is a premalignant condition that is characterised by intestinal metaplasia. Intestinal metaplasia is the term used to describe the replacement of normal squamous epithelium with metaplastic columnar epithelium. The replacement of normal epithelium is induced by chronic gastro-oesophageal reflux, which is a critical factor in the development of the premalignant lesions [28]. BO is diagnosed by histological endoscopy and the identification of intestinal metaplasia is defined by the presence of goblet cells capable of secreting mucous. BO manifests clinically with recurrent GORD, which is associated with constant reflux of bile acids and salts present in the gastric and duodenal juices. Patients diagnosed with GORD are at high risk of developing $\mathrm{BO}$ with $13.2 \%$ of patients progressing to $\mathrm{BO}$ [29].

The presence of dysplasia in $\mathrm{BO}$ is an accurate measure for staging the progression to OAC. A method has thus evolved to identify patients with high risk for developing OAC [30]. Patients undergo routine endoscopies where biopsies are taken for dysplasia grading. When compared to non-dysplastic $\mathrm{BO}$, there is an increased risk of OAC in patients with high grade dysplasia (HGD) and low grade dysplasia (LGD) [28]. The mechanism through which GORD affects the progression is largely unknown but epithelial damage from the altered acidic $\mathrm{pH}$ is strongly associated [31]. Pancreatic enzymes and bile salts are key elements in GORD and may contribute to Barrett's pathogenesis through their injurious effects on the endothelial membranes [32]. Bile salts and the altered acidic $\mathrm{pH}$ can promote inflammation through activation of the arachidonic acid (AA) pathway [33,34]. COX-2 overexpression is seen in $\mathrm{BO}$ and $\mathrm{OAC}$ patients [35], suggesting a role for this inflammatory pathway in OAC development and progression.

\section{Cyclooxygenase Signalling Pathway}

Eicosanoids are derived from the metabolism of AA by COX, lipoxygenase (LOX) and P-450 epoxygenase pathways. They include prostaglandins, leukotrienes and thromboxanes. AA is converted to the prostaglandin precursors, prostaglandin G2 (PGG2) and prostaglandin $\mathrm{H} 2$ (PGH2) by COX enzymes. There are three isoforms of the COX enzyme involved in the production of prostaglandins; the ubiquitously expressed COX-1, the inducible isoform COX-2 and the COX-1 splice variant COX-3 [36]. COX-1 plays a major role in tissue homeostasis through the production of prostaglandins, whereas COX-2 expression is induced in tumourigenic and inflammatory conditions [37]. The prostaglandin precursors PGG2 and PGH2 are further metabolized to prostaglandins by tissue-specific synthases and isomerases. Prostaglandin I2 (PGI2), Prostaglandin F2 $\alpha$ (PGF2 $\alpha$ ), Prostaglandin D2 (PGD2), Thromboxane A2 (TXA2) and PGE2 are produced by PGI synthase, PGF synthase, PGD synthase, TXA synthase and PGE synthase respectively [38]. Prostaglandins activate downstream G-protein-coupled prostanoid receptors in an autocrine or paracrine manner.

PGE2 has many diverse functions and is primarily involved in inflammation, infection and cancer [39]. It functions through binding to EP receptors; EP1, EP2, EP3 and EP4. EP receptors are G-proteincoupled receptors expressed on the plasma membrane and nuclear membrane $[40,41]$. The downstream signalling pathways activated by the PGE2 receptors are discussed in detail in a review by Narumiya et al. [42]. Second messenger levels are altered upon ligand binding of PGE2 to its cognate EP receptors. Upon ligand binding, EP receptors induce the activation of the MAP kinase pathway through cAMP upregulation (EP2, EP3 and EP4) or through the activation of phospholipase C (EP1) (Figure 1) [43].

\section{Cyclooxygenase Signalling and OAC Development/ Progression}

\section{COX and oesophageal adenocarcinoma}

Many cancer studies have been directed at finding a suitable target for therapy and acquiring a greater understanding of the inflammatory pathways involved. Prostaglandins are derived from AA and play a key role in inflammatory processes and diseases. Both GORD and $\mathrm{BO}$ are the major risk factors for the development of OAC. The pathogenesis of both conditions includes chronic inflammation of the oesophageal epithelium.

The persistent inflammation and damage seen in patients with these symptoms has been linked to cancer development. The precise mechanisms underlying these effects are unclear, although the increased production of certain cytokines (IL-1, IL-6 and TNF- $\alpha$ ), transcription factors (NFkB, STAT3), reactive oxygen species and enzymes (COX, nitric oxide synthase) during inflammatory processes have been linked to carcinogenesis [44].

The expression patterns for COX-1 and COX-2 have been determined for healthy oesophageal mucosa. COX-1 and COX-2 were expressed in normal tissue from oesophageal mucosa, with COX-1 expression the most abundant [45]. When compared to normal healthy controls, COX-1 expression significantly decreases in GORD, $\mathrm{BO}$, dysplasia and OAC patient samples $[7,45]$. In both studies, COX-1 gene expression was down-regulated across the adenocarcinoma sequence, thus COX-1 may play a role in the development of oesophageal carcinogenesis. 
Citation: Lowry MC, Reynolds JV, Cathcart MC (2014) The Role of PGE2 and its Corresponding Receptors (Ep1-4) in Oesophageal Carcinogenesis: Novel Therapeutics for Chemoprevention and/or Intervention. J Carcinog Mutagen 5: 181. doi: $10.4172 / 2157-2518.1000181$

Page 3 of 10

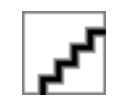

Figure 1: Prostanoids are generated through the COX induced metabolism of arachidonic acid. PGH2 is generated and further metabolized to PGE2, PGF2 $\alpha$, PGD2, PGI2 and TXA2 through specific synthases. PGE2 binds to the G-protein coupled receptors EP1, EP2, EP3 and EP4. EP receptors activate the ERK, STAT and JNK downstream signalling pathways through binding PGE2. Intracellular $\mathrm{Ca} 2+$ is increased through EP1 receptor activation. cAMP levels are altered through EP2, EP3 and EP4 receptor activation. ATP; adenosine triphosphate, ERK; extracellular-signalregulated kinase, JNK; c-Jun $\mathrm{N}$-terminal kinase, STAT3; signal transducer and activator of transcription 3, Src; proto-oncogene tyrosine-protein kinase, PLC; phospholipase C, DAG; diacylglycerol, PIP2; phosphatidylinositol 4,5-bisphosphate, IP3; inositol trisphosphate, PKC; protein kinase C, cAMP; cyclic adenosine monophosphate, PI3K; Phosphoinositide 3-kinase, PGFS; PGF synthase, PGDS; PGD synthase, PGES; PGE synthase, PGIS; PGI synthase, TxS; thromboxane synthase.

As described previously, COX-2 over-expression is a marker of poor prognosis in a number of cancers, including colorectal cancer, lung cancer, and OAC [4-6]. COX-2 expression is increased in $\mathrm{BO}$ and OAC patients [7,35], although the increased expression observed in Barrett's patients was unaffected by dysplasia grade [46]. Morris et al investigated COX-2 expression in the Barrett's metaplasia-dysplasiaadenocarcinoma sequence of $\mathrm{BO}$ patients. COX-2 expression increased across the sequence towards adenocarcinoma [8]. A more recent study using immunohistochemistry (68 patients) and qPCR (17 patients) in Barrett's and OAC patient biopsies revealed a similar trend of an increased COX-2 expression pattern across the adenocarcinoma sequence. In contrast, qPCR analysis revealed a decrease in COX-1 expression levels in this sequence [45]. Similarly, COX-2 and PGE2 levels were increased in tissue from an oesophageal adenocarcinoma rat model, relative to normal controls. Selective COX-2 inhibition with celecoxib prevented OAC development in this rat model, demonstrating a role for COX-2 and the pro-inflammatory prostanoid, PGE2, in OAC development and progression. Celecoxib is currently the only Food and Drug Administration (FDA)-approved chemopreventive agent, although there are ongoing concerns relating to its safety following chronic use [47]. Selective COX-2 inhibitors (NS-398 and nimesulide) increased apoptosis and reduced cell proliferation in-vitro in a Barrett's-derived oesophageal adenocarcinoma OE-33 cell line. PGE2 production was also suppressed following selective COX-2 inhibition in this model [48]. COX-2 expression, apoptosis and cell proliferation was also altered in Barrett's-associated adenocarcinoma tumour cells (SEG-1 and FLO) using the selective COX-2 inhibitor, ns-398 [49]. These studies indicate that COX-2 targeting may be promising for the treatment of Barrett's-associated OAC.

The COX-2 signalling pathway has frequently been implicated in the promotion of tumour angiogenesis [50]. Bile acids are thought to influence this process in oesophageal cancer via effects on COX-2, EGFR/MAPK pathway and vascular endothelial growth factor (VEGF). A positive association between PGE2 and VEGF production following stimulation of oesophageal squamous cell carcinoma cell lines (KYSE-170 and KYSE-270 cells) with chenodeoxycholic acid [51]. In mouse mammary tumour cells, PGE2 mediated VEGF expression was increased through the activation of the EP2 receptor [52]. COX-2 overexpression has also been associated with tumour angiogenesis and PGE2 production in other G.I. malignancies, including colorectal cancer and gastric cancer [53,54]. It is evident from previous studies of COX-2 in oesophageal cancer that PGE2 is the major COX-2-derived prostanoid involved.

\section{PGE2 is the major COX-derived prostanoid implicated in OAC}

While COX-2 overexpression appears to play a role in OAC development and/or progression, less is known about the involvement of downstream prostanoids. Zimmermann et al. investigated COX-1 and COX-2 expression in OAC patients. Through immunohistochemical and western blot analysis, OAC tissue resections from 27 patients revealed the presence of both COX-2 and COX-1 expression in this cancer type. Via western blot analysis, COX-2 expression was shown to be increased in OAC patient tissue compared to healthy controls [55]. Treatment of the oesophageal squamous tumour cells (OSC-2) with COX-2 inhibitors (NS-398 and flosulide) resulted in enhanced apoptosis and reduced cell proliferation. The anti-tumour effects seen in-vitro correlated with decreased PGE2 production. Based on this evidence, the authors suggest that COX-2 inhibitors may be promising chemopreventive agents, which mediate their effects in part through PGE2 suppression [55]. Barrett's oesophageal epithelial cells were treated with the selective COX-2 inhibitor, NS-398. Upon treatment, COX-2 activity and cell proliferation were significantly inhibited. This effect was reversed with the addition of PGE2, suggesting the involvement of COX-2 in cell proliferation in this model [56]. Apoptotic cell death was induced in colorectal and colon cancer cell lines using selective COX-2 inhibitors (NS-398 and SC-58125) [57,58]. Similarly in oesophageal cell lines, aspirin inhibited cell growth through the induction of apoptosis and decreased PGE2 production [59]. Further research is required to understand the exact role of PGE2 in BO and the progression to $\mathrm{OAC}$, as well as the signalling mechanisms involved. COX-2 induces PGE2 release and cell proliferation in Barrett's patients [34]. These COX-2 dependent pathways were shown to be induced through acid- and bile-salts. Targeting the COX-2/PGE2 pathway is of particular interest as a chemopreventive approach in GI malignancies. A recent phase II clinical trial recruited 114 Barrett's patients who underwent drug therapy with low or high doses of aspirin $(81 \mathrm{mg} / 325 \mathrm{mg}$ once daily) and esomeprazole (40 mg twice daily) for 28 days. $22 \%$ of patients presented with adverse events including hiatal hernia, gastro-oesophageal junction erosion and antral erosion. PGE2 levels were significantly reduced in patients treated with high dose aspirin and esomeprazole, suggesting that PGE2 suppression may play a role in preventing $\mathrm{BO}$ progression to $\mathrm{OAC}$ [60]. Further clinical trials are required to greater understand the mechanisms involved.

\section{Downstream EP receptor signalling in $\mathrm{BO}$ and OAC}

In the early 1960's, Bergstrom et al. isolated and determined the structural characteristics of prostaglandins $[61,62]$. EP receptors were not successfully cloned until the early 1990's [63-66]. Since then, the development of EP antagonists for all the EP receptors has been slow with the first selective EP2 antagonist only developed in 2011 [67]. EP1 antagonists however, were studied as potential anti-inflammatory 
Citation: Lowry MC, Reynolds JV, Cathcart MC (2014) The Role of PGE2 and its Corresponding Receptors (Ep1-4) in Oesophageal Carcinogenesis: Novel Therapeutics for Chemoprevention and/or Intervention. J Carcinog Mutagen 5: 181. doi: $10.4172 / 2157-2518.1000181$

Page 4 of 10

drugs as far back as 1977 [68]. They would later be shown to reduce polyp size in a mouse of model of colon cancer [69]. This was one of the first studies to elicit the emerging and significant interest in the use of EP receptor antagonists in cancer prevention and/or treatment. EP receptor targeting is gaining considerable interest for the treatment of a number of malignancies including OAC, colorectal cancer, breast cancer and prostate cancer [45,70-72]. Based on previous positive results of EP antagonism in inflammation and many cancers, it may therefore be a suitable target for research in $\mathrm{BO}$ and $\mathrm{OAC}$. In order to fully uncover the role of PGE2 in OAC progression, the downstream $\mathrm{EP}$ receptor signalling molecules must be investigated.

EP receptor expression levels were recently investigated in normal human oesophageal, BO and OAC tissue biopsies [45]. The authors demonstrated that all EP receptor subtypes were expressed in healthy oesophageal tissue. EP2 receptor expression was 56.88 -fold higher in Barrett's oesophageal tissue mRNA $(n=17)$ compared to healthy control tissue mRNA. EP protein expression profiles were determined using immunohistochemistry. EP2 protein expression levels increased significantly across each stage of the Barrett's to adenocarcinoma sequence when compared to controls. The greatest increase in EP2 expression was seen at the Barrett's metaplasia without intraepithelial neoplasia and low-grade intraepithelial neoplasia stages. EP4 expression was also significantly upregulated in BO tissue but not in OAC tissue. EP1 expression was not altered. EP3 expression levels were markedly reduced across the cancer sequence [45]. EP receptor expression profiles were also assessed in a rat reflux model of oesophageal squamous cell dysplasia and Barrett's metaplasia. The authors demonstrated that EP2, EP3 and EP4 levels were increased in the experimental model compared to controls, further supporting a role for these receptors in the progression to OAC [73]. In colorectal cancer, EP1, EP2 and EP4 have been shown to play a role in disease progression (reviewed by Hull et al., [70]). In non-small cell lung cancer (NSCLC), EP2 expression was down-regulated in NSCLC tumour samples. The authors demonstrated that EP receptor expression is epigenetically regulated [74]. This work suggests a role for EP receptor epigenetic therapies in NSCLC. Further studies are required to investigate EP epigenetic regulation in OAC. More recent studies have examined the individual contributions of the EP receptors to OAC using specific receptor antagonists. These studies will be discussed in subsequent sections.

\section{Targeting the COX-pathway for chemoprevention and/or treatment}

Targeting the steps involved in the progressive sequence from $\mathrm{BO}$ to $\mathrm{OAC}$, is an encouraging area of research for the development of effective chemoprevention therapies. Chemopreventive strategies have yet to demonstrate success in preventing the progression to OAC. GORD is the major risk factor associated with $\mathrm{BO}$ progression to OAC, thus proton pump inhibitors (PPIs) were developed to prevent malignant transformation through acid suppression. However, complete acid suppression and thus reduced risk for the development of OAC has yet to be shown in patients [75]. Novel chemopreventative approaches are therefore warranted. The first indication of the antitumour effects of NSAIDs was seen in Gardner's syndrome patients with rectal and colon polyposis. The number of adenomas in patients was significantly reduced when treated with sulindac. This was the first study to suggest that targeting the COX pathway may be advantageous in the chemoprevention and/or intervention of cancer [76]. To date, chemopreventive agents targeting the COX pathway have demonstrated efficacy in many cancers including OAC, colon, nonsmall-cell lung and breast cancer [77-80].

\section{Non-selective COX inhibition}

Traditional NSAIDs have demonstrated chemopreventive properties in OAC development. As described in a meta-analysis review, NSAID use was shown to have a protective effect in a cohort of OAC patients. Data from nine studies, which included 1813 patients, were pooled together. From the pooled results, the use of aspirin was shown to have the greatest protective effects, with a $50 \%$ reduction in the odds ratio of OAC development. A $25 \%$ reduction was evident in patients treated with NSAIDs [81]. NSAIDs have the potential to be used in cancer prevention although concerns have been raised regarding the safety profile of this class of drugs [10]. Aspirin is a nonselective COX-inhibitor which can lead to gastric lesions [82]. However, the 20 -year risk of death due to OAC is significantly reduced upon treatment with aspirin. In OAC trial patients, daily aspirin intake significantly reduced the hazard ratio (HR) from 0.78 (0-5 years' follow-up) to 0.42 (0-20 year's follow-up) [77]. In a meta-analysis, Rothwell et al revealed that subsequent aspirin intake after the initial diagnosis of adenocarcinomas, reduces metastasis and thus cancer death [83].

The Aspirin Esomeprazole Chemoprevention Trial (AspECT) is a phase III clinical trial to determine if the use of aspirin and esomeprazole can reduce cancer development and progression in these patients. This trial commenced enrolling patients in 2005 and will be run over a 10 year period [84]. 2500 Barrett's patients were recruited and will undergo routine endoscopy and biopsy procedures over the 10 years. A dose of $300 \mathrm{mg}$ /day of Aspirin will be given to patients on low and high-dose PPI therapy (esomeprazole). This trial will address the safety and efficacy of COX inhibitors and high dose PPI therapies as suitable chemopreventive treatments for the prevention of the development of OAC and high grade dysplasia in Barrett's patients [85].

\section{Selective COX-2 inhibition}

Selective COX-2 inhibitors were designed in an effort to offset GI toxicity associated with chronic NSAID use. This class of drugs have shown considerable promise in cancer-based studies. However, a moderate increase in cardiovascular events was associated with the use of COX-2 selective inhibitors [74]. A combination of a MF-tricyclic (selective COX-2 inhibitor) and sulindac (NSAID) effectively reduced inflammation and cancer risk in a reflux-induced rat model of OAC. Following the induction of enteroesophageal reflux, PGE2 and COX-2 levels were increased in this model. Rats were treated daily with 30 $\mathrm{mg} / \mathrm{kg}$ of sulindac and $10 \mathrm{mg} / \mathrm{kg}$ of MF-tricyclic for 28 weeks. Following treatment, inflammation, tumour size, PGE2 levels and cancer risk were all reduced [86]. Oyama et al. studied the effects of celecoxib treatment in a rat model of oesophageal metaplasiaadenocarcinoma sequence. Their study led to the discovery that this selective COX-2 inhibitor increased apoptosis but reduced COX-2 expression, cell proliferation and MET expression [87]. Upon treatment with celecoxib, significantly decreased COX-2, MET and VEGF expression was seen in oesophageal cancer cell lines (OE-33 and OE-19). This trend was also seen in OAC patients when using Celecoxib as a neo-adjuvant therapy. Down-regulation of COX-2 and MET was seen in-vivo. VEGF expression was also significantly decreased in treated patients [88]. In light of these observations, a clinical trial was set up to determine the efficacy of Celecoxib in 
Citation: Lowry MC, Reynolds JV, Cathcart MC (2014) The Role of PGE2 and its Corresponding Receptors (Ep1-4) in Oesophageal Carcinogenesis: Novel Therapeutics for Chemoprevention and/or Intervention. J Carcinog Mutagen 5: 181. doi: $10.4172 / 2157-2518.1000181$

Page 5 of 10

patients. In the Chemoprevention for Barrett's Esophagus Trial (CBET), low doses of celecoxib did not prevent the progression to $\mathrm{OAC}$ and side effects occurred in some patients. Adverse events recorded included OAC development, myocardial infarction and pulmonary embolism [89]. Due to the side effects associated with COX-2 inhibitors, targeting downstream effectors of COX-2 signalling may be advantageous. A more-selective approach has the potential to preserve anti-tumour reactivity while avoiding adverse toxicities.

\section{EP receptor antagonism}

Dysregulated EP expression is observed in a number of cancer types, including oesophageal cancer [45]. Selective EP antagonists are now being used to uncover the individual contributions of EP receptors to cancer development and progression. In the oesophageal cancer cell line (OE-33), cell proliferation was inhibited upon treatment with an EP1 antagonist (SC-51322), an EP4 antagonist (AH23848B), a dual EP1/EP2 antagonist (AH6809) and COX-2 inhibitors (NS-398 and SC-58125). In a butyrate-induced apoptotic OE-33 cell line, the EP2 agonist (butaprost) had greater apoptotic inhibitory effects than the addition of exogenous PGE2. It is therefore evident that EP2 plays a protective role in this Barrett's-derived oesophageal adenocarcinoma cell line. Following the addition of exogenous PGE2, EP1, EP2 and EP4 were shown to play a role in OE-33 cell migration. Deoxycholic acid activates COX-2 signalling and increases PGE2 production. EP1, EP2 and EP4 expression were induced in OE-33 cells upon treatment with deoxycholic acid. This study demonstrates that EP receptor expression is induced through the induction of COX-2 and PGE2 production [90]. Using the selective EP2 antagonist, TG4-155 in prostate cancer cell lines, Jianxiong Jiang et al. showed that EP2 is involved in increasing cell proliferation and invasion. EP2 also promotes the production of the inflammatory cytokines and angiogenic IL- 6 and IL- $1 \beta$ in human prostate cancer cell lines (PC3). EP antagonists may therefore prove to be beneficial in inflammation-driven cancers [72]. Tumour angiogenesis was studied in EP2 knockout mice using an in-vivo corneal angiogenesis assay, an ex-vivo aortic ring assay and a $3 \mathrm{D}$ collagen gel assay to measure vascular sprouting. Using this EP2-/- mouse, EP2 signalling was shown to be involved in tumour angiogenesis through its influence on endothelial cell survival and motility [91]. A human OAC mouse model was recently created using human OAC xenografts into nude mice. This model was then used to determine the potential of an EP4 antagonist on tumour activity [92]. Although the results were insignificant, the slight reduction in tumour volume observed following EP4 antagonism highlight the need to investigate EP receptor antagonists further in $\mathrm{OAC}$ development and progression.

Following the discovery of the link between obesity and OAC, leptin levels were shown to increase with increasing BMI [93]. The role of PGE2 is involved in leptin associated proliferation and associated apoptosis inhibition, was demonstrated using an EP4 antagonist. In this study, AH 23848 was used to successfully inhibit cell proliferation and activation of apoptosis in leptin stimulated OE-33 cells [94]. This study reveals another possible pathway involved in the progression of $\mathrm{BO}$ to $\mathrm{OAC}$, in which $\mathrm{EP}$ receptor targeting may prove to be a beneficial chemopreventative approach. A summary of studies carried out to target the cyclooxygenase signalling pathway in OAC development and progression is presented in Table 1. Of course, novel EP-targeted agents are continuously being generated and will be discussed in the following section.

\section{Development of novel selective EP antagonists}

The complete study of EP receptors in cancer has previously been hampered by the lack of a potent and selective EP2 antagonist. While the EP1/EP2 dual antagonist (AH6809) has been commonly used, it only shows poor selectivity for EP2 [95]. In 2011, Forselles et al. developed a novel, potent and "truly selective EP2 receptor antagonist" [67]. This antagonist was shown to maintain its activity in-vivo and thus has the potential to elicit the role of EP2 in the Barrett's metaplasia-dysplasia-adenocarcinoma sequence. Further selective small molecule EP2 antagonists were also developed in 2012 and are also under investigation [96].

Many EP receptor antagonists are now commercially available. Studies to improve the selectivity and safety of these antagonists are ongoing. The characterization of a novel selective EP4 antagonist (CJ-042794) was recently carried out in human blood. When compared to the previously developed CJ-023423 antagonist, CJ-042794 has an altered chemical structure and a 200-fold greater binding affinity for the human EP4 receptor. This antagonist decreased PGE2 related cAMP production in the hEP4/HEK293 cell line [97]. RaQualia Pharma, Inc has also developed the selective EP4 antagonist, RQ-15986. Since its development, RQ-15986 has been shown to inhibit breast cancer metastasis through its protective role on natural killer cells [98]. This recent study broadens the area of EP receptor antagonism research and warrants investigation in other cancer types. Due to the markedly increased expression levels of EP4 in $\mathrm{BO}$ patients, these new agents may have efficacy for the prevention and/or treatment of OAC, where other EP4 antagonists have failed.

Preventing cancer progression is key, but maintaining homeostasis and preventing toxicity is also vital in cancer drug development. In developing new EP antagonists it is important to note the downstream effects and the particular pathways affected by receptor blockade. For example, EP4 receptors have been shown to be play protective roles following ischemic injury, EP1 regulates blood pressure and algesia, EP3 and EP2 are involved in controlling platelet aggregation [99-101]. These downstream effects should be taken into account when targeting these receptors.

While a number of novel, specific EP antagonists have been developed in recent years, clinical trials of these agents are very limited. GSK269984A is an EP1 antagonist developed by GlaxoSmithKline. This antagonist is highly selective for the EP1 receptor, but no correlation was seen between in-vitro and in-vivo studies with this drug [102]. The GSK269984A pharmacokinetics was later determined in a human microdose study. From this exploratory study, GSK269984A was deemed to have a favourable pharmacokinetic profile in humans [103]. This exploratory microdose study may prove beneficial for future drug development studies prior to both first-into-human (FIH) studies and clinical trials. A recent 3way crossover trial was carried out to investigate the effects of an EP4 antagonist, BGC20-1531 in a PGE2-induced human model of headache [104]. While BGC20-1531 did not prevent PGE2-induced cranial artery dilation and headache, no difference in the occurrence of adverse events was reported between the treatment group and the control group. The authors suggested that the negative outcome observed may be partially due to low exposure of the novel antagonist in 3 of the 8 healthy volunteers recruited to the study. While the lack of difference in adverse events is encouraging, the small patient size and short duration of the study suggests that further investigation is warranted to assess the clinical efficacy and safety profile of this agent. The recent availability of an EP2 antagonist will allow further 
Citation: Lowry MC, Reynolds JV, Cathcart MC (2014) The Role of PGE2 and its Corresponding Receptors (Ep1-4) in Oesophageal Carcinogenesis: Novel Therapeutics for Chemoprevention and/or Intervention. J Carcinog Mutagen 5: 181. doi: $10.4172 / 2157-2518.1000181$

Page 6 of 10

investigation into the roles of EP receptors in cancer development and their potential as therapeutics. More clinical trials are needed in this area to fully investigate the potential anti-tumour effects of EP antagonism. However, complete preclinical studies to uncover the potential of EP antagonism must first be carried out.

\section{Conclusion}

Cancer accounted for 8.2 million deaths worldwide in 2012 [105]. In 2014 , it is estimated that $1,665,540$ new cancer cases will be presented and 585,720 cancer deaths will occur in the United States [1]. OAC is the 7th most common cause of cancer deaths worldwide [1]. These staggering figures portray the need for new discoveries, new curative treatments, new chemopreventive therapies and a better understanding of the mechanisms involved in tumourigenesis.

Many steps and processes are involved in the development and progression of cancer. The COX pathway has become one of the major pathways implicated in cancer progression. An increase in COX-2 and PGE2 expression is seen in many tumour states. The COX-2/PGE2 pathway plays a significant role in tumourigenesis of OAC. Traditional NSAIDs and selective COX-2 inhibitors can inhibit oesophageal cancer development but have been associated with an increased risk of gastrointestinal and cardiovascular toxicity. It is therefore evident that the discovery of new molecular targets downstream of COX-2 and PGE2 is required. Selective inhibition of a particular receptor in the COX pathway is unlikely to be sufficient to fully prevent cancer, however. Recent studies suggest that PGE2 receptors (EP) work synergistically and/or sequentially in cancer progression [106,107]. Downstream signalling via EP receptors plays a role in the development of OAC. EP receptor expression varies across the Barrett's metaplasia-dysplasia-adenocarcinoma sequence, indicating their possible roles in carcinogenesis. The data presented in this review suggests that EP2 and EP4 are of particular interest in this disease sequence. EP2 is the most abundant receptor expressed in both $\mathrm{BO}$ and OAC [45]. Down-regulation of EP3 was evident across the Barrett's to adenocarcinoma sequence, an effect which may be attributed in part to epigenetic regulation [45,74]. This area of research has shown considerable promise in a number of cancer types. While studies carried out in OAC to date have also been very promising, they are relatively few and therefore some-what limited. Further research is needed to develop this field and to determine the functional contributions of each EP receptor to OAC development and progression.

Further research efforts into this exciting field will be greatly aided by the constant development of novel EP receptor antagonists. This process is ongoing to improve the potency and selectivity these agents while limiting toxic side effects. Alternative compounds which target EP receptors are also being assessed. Amino thiadiazole amides have selective antagonistic action on rat EP3 receptors and may be used as therapeutic drugs in other disease models [108]. Combined EP receptor antagonism may also be beneficial in the prevention/ treatment of OAC, although this has yet to be investigated. Due to the multiple roles that EP receptors play in cancer progression, it is unsurprising that research is now moving forward to investigate the efficacy of targeting multiple prostanoid receptors. Recently, a patent application has commenced for a multiple prostaglandin receptor antagonist, AGN-211377 (Patent number: PCT/US2011/048361). The group are targeting anti-inflammatory responses with this antagonist but it may also have potential as a cancer therapeutic. Dual EP and dual EP/TP antagonists are commercially available and are undergoing further pre-clinical investigation before moving forward $[109,110]$.

In conclusion, due to the adverse safety profile observed in patients routinely taking COX inhibitors, more effective alternative approaches are warranted for chemoprevention and/or treatment of OAC. The AspECT trial is ongoing and will give a greater insight into the potential of combining aspirin and PPI therapy in Barrett's patients. Greater knowledge of the efficacy and toxicity of both single and combination EP receptor antagonists are warranted in the pre-clinical setting for OAC development/progression. Selective EP antagonism has the potential of avoiding the adverse safety profile associated with global COX-2 inhibition, while retaining anti-tumour efficacy. This approach has demonstrated considerable promise in a number of cancer types, specifically breast cancer and skin cancer $[106,107]$. Given the very limited options for the prevention and/or treatment of $\mathrm{OAC}$, the coming years will be very exciting for this field of research.

\begin{tabular}{|c|c|c|c|c|}
\hline Target & Agent & Mechanism Affected & Model of study & Author \\
\hline COX-1 & $\begin{array}{l}\text { SC-560 } \\
\text { SC-560 } \\
\text { SC-560 }\end{array}$ & $\begin{array}{l}\text { VEGF-C/COX-1 } \\
\text { VEGF-C/COX-1 } \\
\text { VEGF-C/COX-2 }\end{array}$ & $\begin{array}{l}\text { OSC-1 cell line } \\
\text { OE-33 cell line } \\
\text { OSC-2 cell line }\end{array}$ & $\begin{array}{l}{[111]} \\
{[111]} \\
{[111]}\end{array}$ \\
\hline COX-1/COX-2 & $\begin{array}{l}\text { Indomethacin } \\
\text { Aspirin } \\
\text { NSAIDs }\end{array}$ & $\begin{array}{l}\text { PGE2/tumour growth } \\
\text { COX } \\
\text { COX-2 }\end{array}$ & $\begin{array}{l}\text { Xenograft model } \\
\text { Patients } \\
\text { Patients }\end{array}$ & $\begin{array}{l}{[92]} \\
{[112]} \\
{[113]}\end{array}$ \\
\hline cox-2 & $\begin{array}{l}\text { Parecoxib } \\
\text { NS-398 } \\
\text { SC-58125 } \\
\text { SC-58125 } \\
\text { JTE-522 } \\
\text { Quercetin } \\
\text { Nimesulide } \\
\text { MF-tricyclic }\end{array}$ & $\begin{array}{l}\text { PGE2 } \\
\text { PGE2/cell proliferation } \\
\text { PGE2/cell proliferation } \\
\text { Cell proliferation } \\
\text { PGE2 } \\
\text { COX-2/PGE2/apoptosis/proliferation } \\
\text { COX-2/PGE2apoptosis/proliferation } \\
\text { COX-2/PGE2/inflammation/tumour growth } \\
\text { PGE2/inflammation }\end{array}$ & $\begin{array}{l}\text { Xenograft model } \\
\text { Cell line } \\
\text { Cell line } \\
\text { Rat model } \\
\text { Rat model } \\
\text { Cell line } \\
\text { Cell line } \\
\text { Rat model }\end{array}$ & $\begin{array}{l}{[92]} \\
{[90]} \\
{[90]} \\
{[114]} \\
{[115]} \\
{[48]} \\
{[48]} \\
{[86]}\end{array}$ \\
\hline
\end{tabular}


Citation: Lowry MC, Reynolds JV, Cathcart MC (2014) The Role of PGE2 and its Corresponding Receptors (Ep1-4) in Oesophageal Carcinogenesis: Novel Therapeutics for Chemoprevention and/or Intervention. J Carcinog Mutagen 5: 181. doi: $10.4172 / 2157-2518.1000181$

Page 7 of 10

\begin{tabular}{|c|c|c|c|c|}
\hline EP1 & $\begin{array}{l}\text { SC-15322 } \\
\text { ONO-8711 }\end{array}$ & $\begin{array}{l}\text { Cell proliferation } \\
\text { PGE2 }\end{array}$ & $\begin{array}{l}\text { Cell line } \\
\text { Human } \\
\text { Endothelial cells }\end{array}$ & $\begin{array}{l}{[90]} \\
{[116]}\end{array}$ \\
\hline EP1/EP2 & $\begin{array}{l}\text { AH6809 } \\
\text { AH6809 }\end{array}$ & $\begin{array}{l}\text { Cell proliferation } \\
\text { Cell proliferation }\end{array}$ & $\begin{array}{l}\text { Cell line } \\
\text { Rat model }\end{array}$ & $\begin{array}{l}{[90]} \\
{[114]}\end{array}$ \\
\hline EP4 & $\begin{array}{l}\text { AH-23848B } \\
\text { AH-23848B } \\
\text { AH23848 } \\
\text { CJ-042794 }\end{array}$ & $\begin{array}{l}\text { PGE2 } \\
\text { Cell proliferation } \\
\text { Leptin/PGE2 } \\
\text { PGE2/PGE2-induced cAMP levels }\end{array}$ & $\begin{array}{l}\text { Xenograft model } \\
\text { Cell line } \\
\text { Cell line } \\
\text { Cell line and human whole } \\
\text { blood }\end{array}$ & $\begin{array}{l}{[92]} \\
{[90]} \\
{[94]} \\
{[97]}\end{array}$ \\
\hline
\end{tabular}

Table 1: The COX inhibitors and EP antagonists currently available and being used in OAC models. This table sets out the drug targets, the specific mechanisms affected and the specific models used. cAMP; cyclic adenosine monophosphate.

\section{Acknowledgements}

This work was supported by a project grant from the Health Research Board (grant number: HRA_POR/2013/286) and a fellowship grant from the Irish Cancer Society (registered charity CHY5863, grant number: CRF11CAT).

\section{References}

1. Siegel R, Ma J, Zou Z, Jemal A (2014) Cancer statistics, 2014. CA Cancer J Clin 64: 9-29.

2. Cook MB, Chow WH, Devesa SS (2009) Oesophageal cancer incidence in the United States by race, sex, and histologic type, 1977-2005. Br J Cancer 101: 855-859.

3. Eloubeidi MA, Mason AC, Desmond RA, El-Serag HB (2003) Temporal trends (1973-1997) in survival of patients with esophageal adenocarcinoma in the United States: a glimmer of hope? Am J Gastroenterol 98: 1627-1633.

4. Bhandari P, Bateman AC, Mehta RL, Stacey BS, Johnson P, et al. (2006) Prognostic significance of cyclooxygenase-2 (COX-2) expression in patients with surgically resectable adenocarcinoma of the oesophagus. BMC Cancer 6: 134.

5. Khuri FR, Wu H, Lee JJ, Kemp BL, Lotan R, et al. (2001) Cyclooxygenase-2 overexpression is a marker of poor prognosis in stage I non-small cell lung cancer. Clin Cancer Res 7: 861-867.

6. Tomozawa S, Tsuno NH, Sunami E, Hatano K, Kitayama J, et al. (2000) Cyclooxygenase-2 overexpression correlates with tumour recurrence, especially haematogenous metastasis, of colorectal cancer. Br J Cancer 83: 324-328.

7. Kuramochi H, Vallböhmer D, Uchida K, Schneider S, Hamoui N, et al. (2004) Quantitative, tissue-specific analysis of cyclooxygenase gene expression in the pathogenesis of Barrett's adenocarcinoma. J Gastrointest Surg 8: 1007-1016.

8. Morris CD, Armstrong GR, Bigley G, Green H, Attwood SE (2001) Cyclooxygenase-2 expression in the Barrett's metaplasia-dysplasiaadenocarcinoma sequence. Am J Gastroenterol 96: 990-996.

9. Farrow DC, Vaughan TL, Hansten PD, Stanford JL, Risch HA, et al. (1998) Use of aspirin and other nonsteroidal anti-inflammatory drugs and risk of esophageal and gastric cancer. Cancer Epidemiol Biomarkers Prev 7: 97-102.

10. Rostom A, Moayyedi P, Hunt R, Canadian Association of Gastroenterology Consensus Group (2009) Canadian consensus guidelines on long-term nonsteroidal anti-inflammatory drug therapy and the need for gastroprotection: benefits versus risks. Aliment Pharmacol Ther 29: 481-496.
11. Scheiman JM, Yeomans ND, Talley NJ, Vakil N, Chan FK, et al. (2006) Prevention of ulcers by esomeprazole in at-risk patients using nonselective NSAIDs and COX-2 inhibitors. Am J Gastroenterol 101: 701-710.

12. Bresalier RS, Sandler RS, Quan H, Bolognese JA, Oxenius B, et al. (2005) Cardiovascular events associated with rofecoxib in a colorectal adenoma chemoprevention trial. N Engl J Med 352: 1092-1102.

13. Devesa SS, Blot WJ, Fraumeni JF Jr (1998) Changing patterns in the incidence of esophageal and gastric carcinoma in the United States. Cancer 83: 2049-2053.

14. Brown LM, Devesa SS, Chow WH (2008) Incidence of adenocarcinoma of the esophagus among white Americans by sex, stage, and age. J Natl Cancer Inst 100: 1184-1187.

15. Dawsey SP, Tonui S, Parker RK, Fitzwater JW, Dawsey SM, et al. (2010) Esophageal cancer in young people: a case series of 109 cases and review of the literature. PLoS One 5: e14080.

16. Su Z, Gay LJ, Strange A, Palles C, Band G, et al. (2012) Common variants at the MHC locus and at chromosome 16q24.1 predispose to Barrett's esophagus. Nat Genet 44: 1131-1136.

17. Martin V, Shaw-Smith C (2010) Review of genetic factors in intestinal malrotation. Pediatr Surg Int 26: 769-781.

18. World Health Organisation.

19. Hanahan D1, Weinberg RA (2011) Hallmarks of cancer: the next generation. Cell 144: 646-674.

20. Eaden JA, Abrams KR, Mayberry JF (2001) The risk of colorectal cancer in ulcerative colitis: a meta-analysis. Gut 48: 526-535.

21. Hvid-Jensen F, Pedersen L, Drewes AM, Sørensen HT, Funch-Jensen P (2011) Incidence of adenocarcinoma among patients with Barrett's esophagus. N Engl J Med 365: 1375-1383.

22. Pouplard C, Brenaut E, Horreau C, Barnetche T, Misery L, et al. (2013) Risk of cancer in psoriasis: a systematic review and meta-analysis of epidemiological studies. J Eur Acad Dermatol Venereol : 36-46.

23. Bernstein CN, Blanchard JF, Kliewer E, Wajda A (2001) Cancer risk in patients with inflammatory bowel disease: a population-based study. Cancer 91: 854-862.

24. Barak N, Ehrenpreis ED, Harrison JR, Sitrin MD (2002) Gastrooesophageal reflux disease in obesity: pathophysiological and therapeutic considerations. Obes Rev 3: 9-15.

25. de Jonge PJ, van Blankenstein M, Looman CW, Casparie MK, Meijer GA, et al. (2010) Risk of malignant progression in patients with Barrett's oesophagus: a Dutch nationwide cohort study. Gut 59: 1030-1036.

26. Cook MB, Shaheen NJ, Anderson LA, Giffen C, Chow WH, et al. (2012) Cigarette smoking increases risk of Barrett's esophagus: an analysis of the Barrett's and Esophageal Adenocarcinoma Consortium. Gastroenterology 142: 744-753. 
Citation: Lowry MC, Reynolds JV, Cathcart MC (2014) The Role of PGE2 and its Corresponding Receptors (Ep1-4) in Oesophageal Carcinogenesis: Novel Therapeutics for Chemoprevention and/or Intervention. J Carcinog Mutagen 5: 181. doi: $10.4172 / 2157-2518.1000181$

Page 8 of 10

27. Cook MB, Kamangar F, Whiteman DC, Freedman ND, Gammon MD, et al. (2010) Cigarette smoking and adenocarcinomas of the esophagus and esophagogastric junction: a pooled analysis from the international BEACON consortium. J Natl Cancer Inst 102: 1344-1353.

28. Fléjou JF (2005) Barrett's oesophagus: from metaplasia to dysplasia and cancer. Gut 54 Suppl 1: i6-12.

29. Westhoff B, Brotze S, Weston A, McElhinney C, Cherian R, et al. (2005) The frequency of Barrett's esophagus in high-risk patients with chronic GERD. Gastrointest Endosc 61: 226-231.

30. Wang KK, Sampliner RE; Practice Parameters Committee of the American College of Gastroenterology (2008) Updated guidelines 2008 for the diagnosis, surveillance and therapy of Barrett's esophagus. Am J Gastroenterol 103: 788-797.

31. Fitzgerald RC, Omary MB, Triadafilopoulos G (1996) Dynamic effects of acid on Barrett's esophagus. An ex vivo proliferation and differentiation model. J Clin Invest 98: 2120-2128.

32. Bhardwaj A, McGarrity TJ, Stairs DB, Mani H (2012) Barrett's Esophagus: Emerging Knowledge and Management Strategies. Patholog Res Int 2012: 814146.

33. Burnat G, Majka J, Konturek PC (2010) Bile acids are multifunctional modulators of the Barrett's carcinogenesis. J Physiol Pharmacol 61: 185-192.

34. Kaur BS, Triadafilopoulos G (2002) Acid- and bile-induced PGE(2) release and hyperproliferation in Barrett's esophagus are COX-2 and PKC-epsilon dependent. Am J Physiol Gastrointest Liver Physiol 283: G327-334.

35. Wilson KT, Fu S, Ramanujam KS, Meltzer SJ (1998) Increased expression of inducible nitric oxide synthase and cyclooxygenase-2 in Barrett's esophagus and associated adenocarcinomas. Cancer Res 58: 2929-2934.

36. Snipes JA, Kis B, Shelness GS, Hewett JA, Busija DW (2005) Cloning and characterization of cyclooxygenase- $1 \mathrm{~b}$ (putative cyclooxygenase-3) in rat. J Pharmacol Exp Ther 313: 668-676.

37. Morita I (2002) Distinct functions of COX-1 and COX-2. Prostaglandins Other Lipid Mediat 68-69: 165-75.

38. Simmons DL, Botting RM, Hla T (2004) Cyclooxygenase isozymes: the biology of prostaglandin synthesis and inhibition. Pharmacol Rev 56: 387-437.

39. Dey I, Lejeune M, Chadee K (2006) Prostaglandin E2 receptor distribution and function in the gastrointestinal tract. Br J Pharmacol 149: 611-623.

40. Bhattacharya M, Peri KG, Almazan G, Ribeiro-da-Silva A, Shichi H, et al. (1998) Nuclear localization of prostaglandin E2 receptors. Proc Natl Acad Sci U S A 95: 15792-15797.

41. Bhattacharya M, Peri K, Ribeiro-da-Silva A, Almazan G, Shichi H, et al. (1999) Localization of functional prostaglandin E2 receptors EP3 and EP4 in the nuclear envelope. J Biol Chem 274: 15719-15724.

42. Narumiya S, Sugimoto Y, Ushikubi F (1999) Prostanoid receptors: structures, properties, and functions. Physiol Rev 79: 1193-1226.

43. Bos CL, Richel DJ, Ritsema T, Peppelenbosch MP, Versteeg HH (2004) Prostanoids and prostanoid receptors in signal transduction. Int J Biochem Cell Biol 36: 1187-1205.

44. Colotta F, Allavena P, Sica A, Garlanda C, Mantovani A (2009) Cancerrelated inflammation, the seventh hallmark of cancer: links to genetic instability. Carcinogenesis 30: 1073-1081.

45. Jiménez P, Piazuelo E, Cebrian C, Ortego J, Strunk M, et al. (2010) Prostaglandin EP2 receptor expression is increased in Barrett's oesophagus and oesophageal adenocarcinoma. Aliment Pharmacol Ther 31: 440-451.

46. Kandil HM, Tanner G, Smalley W, Halter S, Radhika A, et al. (2001) Cyclooxygenase-2 expression in Barrett's esophagus. Dig Dis Sci 46: 785-789.

47. Zhang T, Su LW, Zhu YF, Lang HJ, Zhang F,et al. (2012) An experimental study on chemoprevention of esophageal adenocarcinoma by celecoxib, a selective cyclooxygenase- 2 inhibitor. Zhonghua Wei Chang Wai Ke Za Zhi: 512-516.
48. Cheong E, Ivory K, Doleman J, Parker ML, Rhodes M, et al. (2004) Synthetic and naturally occurring COX-2 inhibitors suppress proliferation in a human oesophageal adenocarcinoma cell line (OE33) by inducing apoptosis and cell cycle arrest. Carcinogenesis: 1945-1952.

49. Souza RF, Shewmake K, Beer DG, Cryer B, Spechler SJ (2000) Selective inhibition of cyclooxygenase-2 suppresses growth and induces apoptosis in human esophageal adenocarcinoma cells. Cancer Res 60: 5767-5772.

50. Trifan OC, Hla T (2003) Cyclooxygenase-2 modulates cellular growth and promotes tumorigenesis. J Cell Mol Med 7: 207-222.

51. Soma T, Kaganoi J, Kawabe A, Kondo K, Tsunoda S, et al. (2006) Chenodeoxycholic acid stimulates the progression of human esophageal cancer cells: A possible mechanism of angiogenesis in patients with esophageal cancer. Int J Cancer 119: 771-782.

52. Chang SH, Liu CH, Wu MT, Hla T, (2005) Regulation of vascular endothelial cell growth factor expression in mouse mammary tumor cells by the EP2 subtype of the prostaglandin E2 receptor. Prostaglandins Other Lipid Mediat,: 48-58.

53. Uefuji K1, Ichikura T, Mochizuki H (2000) Cyclooxygenase-2 expression is related to prostaglandin biosynthesis and angiogenesis in human gastric cancer. Clin Cancer Res 6: 135-138.

54. Tsujii M, Kawano S, Tsuji S, Sawaoka H, Hori M, et al. (1998) Cyclooxygenase regulates angiogenesis induced by colon cancer cells. Cell 93: 705-716.

55. Zimmermann KC, Sarbia M, Weber AA, Borchard F, Gabbert HE, et al. (1999) Cyclooxygenase-2 expression in human esophageal carcinoma. Cancer Res 59: 198-204.

56. Buttar NS, Wang KK, Anderson MA, Dierkhising RA, Pacifico RJ, et al. (2002) The effect of selective cyclooxygenase-2 inhibition in Barrett's esophagus epithelium: an in vitro study. J Natl Cancer Inst 94: 422-429.

57. Sheng H, Shao J, Kirkland SC, Isakson P, Coffey RJ, et al. (1997) Inhibition of human colon cancer cell growth by selective inhibition of cyclooxygenase-2. J Clin Invest 99: 2254-2259.

58. Elder DJ, Halton DE, Hague A, Paraskeva C (1997) Induction of apoptotic cell death in human colorectal carcinoma cell lines by a cyclooxygenase-2 (COX-2)-selective nonsteroidal anti-inflammatory drug: independence from COX-2 protein expression. Clin Cancer Res 3: 1679-1683.

59. Li M, Lotan R, Levin B, Tahara E, Lippman SM, et al. (2000) Aspirin induction of apoptosis in esophageal cancer: a potential for chemoprevention. Cancer Epidemiol Biomarkers Prev 9: 545-549.

60. Falk GW, Buttar NS, Foster NR, Ziegler KL, Demars CJ, et al. (2012) A combination of esomeprazole and aspirin reduces tissue concentrations of prostaglandin $\mathrm{E}(2)$ in patients with Barrett's esophagus. Gastroenterology 143: 917-926.

61. Bergstrom S (1963) Prostaglandins--a group of hormonal compounds of widespread occurrence. Biochem Pharmacol 12: 413-414.

62. Bergstrom S, Samuelsson B (1962) Isolation of prostaglandin E1 from human seminal plasma. Prostaglandins and related factors. 11. J Biol Chem 237: 3005-3006.

63. Funk CD, Furci L, FitzGerald GA, Grygorczyk R, Rochette C, et al. (1993) Cloning and expression of a cDNA for the human prostaglandin $\mathrm{E}$ receptor EP1 subtype. J Biol Chem 268: 26767-26772.

64. Bastien L, Sawyer N, Grygorczyk R, Metters KM, Adam M (1994) Cloning, functional expression, and characterization of the human prostaglandin E2 receptor EP2 subtype. J Biol Chem 269: 11873-11877.

65. Sugimoto Y, Namba T, Honda A, Hayashi Y, Negishi M, et al. (1992) Cloning and expression of a cDNA for mouse prostaglandin $\mathrm{E}$ receptor EP3 subtype. J Biol Chem 267: 6463-6466.

66. An S, Yang J, Xia M, Goetzl EJ (1993) Cloning and expression of the EP2 subtype of human receptors for prostaglandin E2. Biochem Biophys Res Commun 197: 263-270.

67. Forselles KJ, Root J, Clarke T, Davey D, Aughton K, et al. (2011) In vitro and in vivo characterization of PF-04418948, a novel, potent and selective prostaglandin EPâ,, receptor antagonist. Br J Pharmacol 164: 1847-1856. 
Citation: Lowry MC, Reynolds JV, Cathcart MC (2014) The Role of PGE2 and its Corresponding Receptors (Ep1-4) in Oesophageal Carcinogenesis: Novel Therapeutics for Chemoprevention and/or Intervention. J Carcinog Mutagen 5: 181. doi: $10.4172 / 2157-2518.1000181$

Page 9 of 10

68. Barbieri EJ, Orzechowski RF, Rossi GV (1977) Measurement of prostaglandin E2 in an inflammatory exudate: effects of nonsteroidal anti-inflammatory agents. J Pharmacol Exp Ther 201: 769-777.

69. Sasai H, Masaki M, Wakitani K (2000) Suppression of polypogenesis in a new mouse strain with a truncated Apc(Delta474) by a novel COX-2 inhibitor, JTE-522. Carcinogenesis 21: 953-958.

70. Hull MA, Ko SC, Hawcroft G (2004) Prostaglandin EP receptors: targets for treatment and prevention of colorectal cancer? Mol Cancer Ther 3: 1031-1039.

71. Ma X, Kundu N, Rifat S, Walser T, Fulton AM (2006) Prostaglandin E receptor EP4 antagonism inhibits breast cancer metastasis. Cancer Res 66: 2923-2927.

72. Jiang J, Dingledine R (2013) Role of prostaglandin receptor EP2 in the regulations of cancer cell proliferation, invasion, and inflammation. J Pharmacol Exp Ther 344: 360-367.

73. Jang TJ, Min SK, Bae JD, Jung KH, Lee JI, et al. (2004) Expression of cyclooxygenase 2, microsomal prostaglandin E synthase 1, and EP receptors is increased in rat oesophageal squamous cell dysplasia and Barrett's metaplasia induced by duodenal contents reflux. Gut 53: 27-33.

74. Gray SG, Al-Sarraf N, Baird AM, Cathcart MC, McGovern E, et al. (2009) Regulation of EP receptors in non-small cell lung cancer by epigenetic modifications. Eur J Cancer 45: 3087-3097.

75. Cooper BT, Chapman W, Neumann CS, Gearty JC (2006) Continuous treatment of Barrett's oesophagus patients with proton pump inhibitors up to 13 years: observations on regression and cancer incidence. Aliment Pharmacol Ther 23: 727-733.

76. Waddell WR, Loughry RW (1983) Sulindac for polyposis of the colon. J Surg Oncol 24: 83-87.

77. Rothwell PM, Fowkes FG, Belch JF, Ogawa H, Warlow CP, et al. (2011) Effect of daily aspirin on long-term risk of death due to cancer: analysis of individual patient data from randomised trials. Lancet 377: 31-41.

78. Reddy BS, Hirose Y, Lubet R, Steele V, Kelloff G, et al. (2000) Chemoprevention of colon cancer by specific cyclooxygenase- 2 inhibitor, celecoxib, administered during different stages of carcinogenesis. Cancer Res 60: 293-297.

79. Altorki NK, Keresztes RS, Port JL, Libby DM, Korst RJ, et al. (2003) Celecoxib, a selective cyclo-oxygenase- 2 inhibitor, enhances the response to preoperative paclitaxel and carboplatin in early-stage non-small-cell lung cancer. J Clin Oncol 21: 2645-2650.

80. BrandÃ£o RD, Veeck J, Van de Vijver KK, Lindsey P, de Vries B, et al. (2013) A randomised controlled phase II trial of pre-operative celecoxib treatment reveals anti-tumour transcriptional response in primary breast cancer. Breast Cancer Res 15: R29.

81. Corley DA, Kerlikowske K, Verma R, Buffler P (2003) Protective association of aspirin/NSAIDs and esophageal cancer: a systematic review and meta-analysis. Gastroenterology 124: 47-56.

82. Abnet CC, Freedman ND, Kamangar F, Leitzmann MF, Hollenbeck AR, et al. (2009) Non-steroidal anti-inflammatory drugs and risk of gastric and oesophageal adenocarcinomas: results from a cohort study and a meta-analysis. Br J Cancer 100: 551-557.

83. Rothwell PM, Wilson M, Price JF, Belch JF, Meade TW, et al. (2012) Effect of daily aspirin on risk of cancer metastasis: a study of incident cancers during randomised controlled trials. Lancet 379: 1591-1601.

84. Das D, Chilton AP, Jankowski JA (2009) Chemoprevention of oesophageal cancer and the AspECT trial. Recent Results Cancer Res 181: 161-169.

85. Clinical Trials (2006)

86. Buttar NS, Wang KK, Leontovich O, Westcott JY, Pacifico RJ, et al. (2002) Chemoprevention of esophageal adenocarcinoma by COX-2 inhibitors in an animal model of Barrett's esophagus. Gastroenterology 122: 1101-1112.

87. Oyama K, Fujimura T, Ninomiya I, Miyashita T, Kinami S, et al. (2005) A COX-2 inhibitor prevents the esophageal inflammation-metaplasiaadenocarcinoma sequence in rats. Carcinogenesis 26: 565-570.
88. Tuynman JB,Buskens CJ, Kemper K, ten Kate FJ, Offerhaus GJ, et al. (2005) Neoadjuvant selective COX-2 inhibition down-regulates important oncogenic pathways in patients with esophageal adenocarcinoma. Ann Surg 242: 840-849, discussion 849-50.

89. Heath EI, Canto MI, Piantadosi S, Montgomery E, Weinstein WM, et al. (2007) Secondary chemoprevention of Barrett's esophagus with celecoxib: results of a randomized trial. J Natl Cancer Inst 99: 545-557.

90. Piazuelo E, JimÃ@nez P, Strunk M, Santander S, GarcÃa A, et al. (2006) Effects of selective PGE2 receptor antagonists in esophageal adenocarcinoma cells derived from Barrett's esophagus. Prostaglandins Other Lipid Mediat 81: 150-161.

91. Kamiyama M, Pozzi A, Yang L, DeBusk LM, Breyer RM, et al. (2006) EP2, a receptor for PGE2, regulates tumor angiogenesis through direct effects on endothelial cell motility and survival. Oncogene 25: 7019-7028.

92. Santander S, Cebri $\tilde{A}_{j n}$ C, Esquivias P, Conde B, Esteva F, et al. (2012) Cyclooxygenase inhibitors decrease the growth and induce regression of human esophageal adenocarcinoma xenografts in nude mice. Int J Oncol 40: 527-534.

93. Considine RV, Sinha MK, Heiman ML, Kriauciunas A, Stephens TW, et al. (1996) Serum immunoreactive-leptin concentrations in normalweight and obese humans. N Engl J Med 334: 292-295.

94. Ogunwobi O, Mutungi G, Beales IL, (2006) Leptin stimulates proliferation and inhibits apoptosis in Barrett's esophageal adenocarcinoma cells by cyclooxygenase-2-dependent, prostaglandin-E2mediated transactivation of the epidermal growth factor receptor and cJun NH2-terminal kinase activation. Endocrinology: 4505-4516.

95. Abramovitz M, Adam M, Boie Y, Carrière M, Denis D, et al. (2000) The utilization of recombinant prostanoid receptors to determine the affinities and selectivities of prostaglandins and related analogs. Biochim Biophys Acta 1483: 285-293.

96. Jiang J, Ganesh T, Du Y, Quan Y, Serrano G, et al. (2012) Small molecule antagonist reveals seizure-induced mediation of neuronal injury by prostaglandin E2 receptor subtype EP2. Proc Natl Acad Sci U S A 109: 3149-3154.

97. Murase A, Taniguchi Y, Tonai-Kachi H, Nakao K, Takada J (2008) In vitro pharmacological characterization of CJ-042794, a novel, potent, and selective prostaglandin EP(4) receptor antagonist. Life Sci 82: 226-232.

98. Ma X, Holt D, Kundu N, Reader J, Goloubeva O, et al. (2013) A prostaglandin E (PGE) receptor EP4 antagonist protects natural killer cells from PGE2-mediated immunosuppression and inhibits breast cancer metastasis. Oncoimmunology 2: e22647.

99. Liang X, Lin L, Woodling NS, Wang Q, Anacker C, et al. (2011) Signaling via the prostaglandin Eâ,, receptor EP4 exerts neuronal and vascular protection in a mouse model of cerebral ischemia. J Clin Invest 121: 4362-4371.

100. Petrucci G, De Cristofaro R, Rutella S, Ranelletti FO, Pocaterra D, et al. (2011) Prostaglandin E2 differentially modulates human platelet function through the prostanoid EP2 and EP3 receptors. J Pharmacol Exp Ther 336: 391-402.

101. Stock JL, Shinjo K, Burkhardt J, Roach M, Taniguchi K, et al. (2001) The prostaglandin E2 EP1 receptor mediates pain perception and regulates blood pressure. J Clin Invest 107: 325-331.

102. Hall A, Brown SH, Budd C, Clayton NM, Giblin GM, et al. (2009) Discovery of GSK345931A: An EP(1) receptor antagonist with efficacy in preclinical models of inflammatory pain. Bioorg Med Chem Lett 19: 497-501.

103. Ostenfeld T, Beaumont C, Bullman J, Beaumont M, Jeffrey P (2012) Human microdose evaluation of the novel EP1 receptor antagonist GSK269984A. Br J Clin Pharmacol 74: 1033-1044.

104. Antonova M, Wienecke T, Maubach K, Thomas E, Olesen J, et al. (2011) The pharmacological effect of BGC20-1531, a novel prostanoid EP4 receptor antagonist, in the prostaglandin E2 human model of headache. J Headache Pain 12: 551-559.

105. World Health Organisation. (2014) 
Citation: Lowry MC, Reynolds JV, Cathcart MC (2014) The Role of PGE2 and its Corresponding Receptors (Ep1-4) in Oesophageal Carcinogenesis: Novel Therapeutics for Chemoprevention and/or Intervention. J Carcinog Mutagen 5: 181. doi: $10.4172 / 2157-2518.1000181$

Page 10 of 10

106. Sung YM, He G, Fischer SM (2005) Lack of expression of the EP2 but not EP3 receptor for prostaglandin E2 results in suppression of skin tumor development. Cancer Res 65: 9304-9311.

107. Chang SH, Liu CH, Conway R, Han DK, Nithipatikom K, et al. (2004) Role of prostaglandin E2-dependent angiogenic switch in cyclooxygenase 2-induced breast cancer progression. Proc Natl Acad Sci U S A 101: 591-596.

108. Hilfiker MA, Wang N, Hou X, Du Z, Pullen MA, et al. (2009) Discovery of novel aminothiadiazole amides as selective $\mathrm{EP}(3)$ receptor antagonists. Bioorg Med Chem Lett 19: 4292-4295.

109. Downey JD, Saleh SA, Bridges TM, Morrison RD, Daniels JS, et al. (2013) Development of an in vivo active, dual EP1 and EP3 selective antagonist based on a novel acyl sulfonamide bioisostere. Bioorg Med Chem Lett 23: 37-41.

110. Kundu N, Ma X, Kochel T, Goloubeva O, Staats P, et al. (2014) Prostaglandin E receptor EP4 is a therapeutic target in breast cancer cells with stem-like properties. Breast Cancer Res Treat 143: 19-31.

111. von Rahden BH, Stein HJ, PÃ $1 / 4$ hringer F, Koch I, Langer R, et al. (2005) Coexpression of cyclooxygenases (COX-1, COX-2) and vascular endothelial growth factors (VEGF-A, VEGF-C) in esophageal adenocarcinoma. Cancer Res 65: 5038-5044.

112. Sivarasan N, Smith G (2013) Role of aspirin in chemoprevention of esophageal adenocarcinoma: a meta-analysis. J Dig Dis 14: 222-230.

113. Liao LM, Vaughan TL, Corley DA, Cook MB, Casson AG, et al. (2012) Nonsteroidal anti-inflammatory drug use reduces risk of adenocarcinomas of the esophagus and esophagogastric junction in a pooled analysis. Gastroenterology 142: 442-452.

114. Piazuelo E, Santander S, Cebrián C, Jiménez P, Pastor C, et al. (2012) Characterization of the prostaglandin E2 pathway in a rat model of esophageal adenocarcinoma. Curr Cancer Drug Targets 12: 132-143.

115. Li Z, Shimada Y, Kawabe A, Sato F, Maeda M, et al. (2001) Suppression of N-nitrosomethylbenzylamine (NMBA)-induced esophageal tumorigenesis in F344 rats by JTE-522, a selective COX-2 inhibitor. Carcinogenesis 22: 547-551.

116. Kaneshiro $\mathrm{T}$, Okumura $\mathrm{M}$, Kawamori $\mathrm{T}$ (2009) Inhibition of prostaglandin $\mathrm{E}(2)$ signaling through the $\mathrm{EP}(1)$ receptor does not affect prostacyclin production in human endothelial cells. Prostaglandins Other Lipid Mediat : 31-36. 